
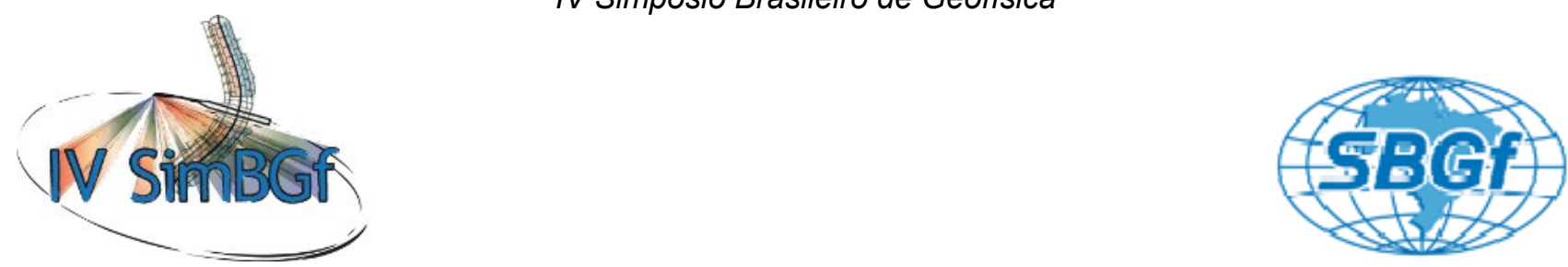

\title{
Determination of Basement Depth and Basalt Thickness in the Paraná Basin with High- Frequency Receiver Function
}

Fabio Dias, Marcelo Assumpção, Renato Prado, José Roberto Barbosa (IAG-USP)

Copyright 2010, SBGf - Sociedade Brasileira de Geofísica

Este texto foi preparado para a apresentação no IV Simpósio Brasileiro de Geofísica, Belém, 14 a 17 de novembro de 2010. Seu conteúdo foi revisado pelo Comitê Técnico do IV SimBGf, mas não necessariamente representa a opinião da SBGf ou de seus associados. É proibida a reprodução total ou parcial deste material para propósitos comerciais sem prévia autorização da SBGf.

\begin{abstract}
Studies of the Parana Basin sedimentary structure have been made in Bebedouro County (SE Brazil) with receiver function (RF) and other geophysical surveys (time-domain electromagnetic, shallow seismics, magnetotelluric). This region is conveniently located $15^{\circ}$ to $20^{\circ}$ away from the deep earthquakes in the Nazca subduction zone making it possible to record high-frequency P-waves $(\sim 10 \mathrm{~Hz})$ useful to investigate detailed structure of shallow sedimentary layers. We will show results of joint inversion of RF and surface wave dispersion curves constrained with shallow seismic data. Rayleigh wave dispersion curves across the network were obtained by crosscorrelation of more than one hundred days of ambient seismic noise ("microseismic waves"). Preliminary results showed a basaltic layer with thickness between 400 and $600 \mathrm{~m}$, under a superficial sandstone layer between 50 and $100 \mathrm{~m}$ thick. Basement depths were estimated between 2 and $3 \mathrm{~km}$. These results are in agreement with expected values for this region of the Parana Basin showing that high-frequency RFs are useful to study sedimentary basins.
\end{abstract}

\section{Introduction}

Since 2004, the population of the Andes district, Bebedouro-SP, started to feel small earthquakes. A seismographic network installed in 2005 showed that the earthquakes are induced by local deep wells used for irrigation (Assumpção et al., 2007; Assumpção et al., 2010).

Bebedouro is located in NW of São Paulo state in the Paraná Basin, where a thin layer of Adamantina sandstones (50 a $100 \mathrm{~m}$ ) overlies basalts of Serra Geral formation (300 a $500 \mathrm{~m}$ ), Botucatu sandstones (Guarani aquifer) and other formations (Milani el al., 1994).

A better knowledge of the thickness of the basalt, and its variations in the area, is important to study the local seismic activity triggered by wells. A better determination of the basalt thickness and other features of the sedimentary layer under the basalt may help in the planning and exploration of underground hydro resources, since this exploration increases every year.

Receiver functions (RFs) are powerful tools to study the crust and upper mantle structures. RFs are a temporal series obtained with the three components of teleseismic events that show the structure beneath the station. They are obtained by deconvolution of vertical with the radial component. This process eliminates the source and path effects, making the RFs dependent only on the structure beneath the station. The stations used in this study are shown in figure 1.

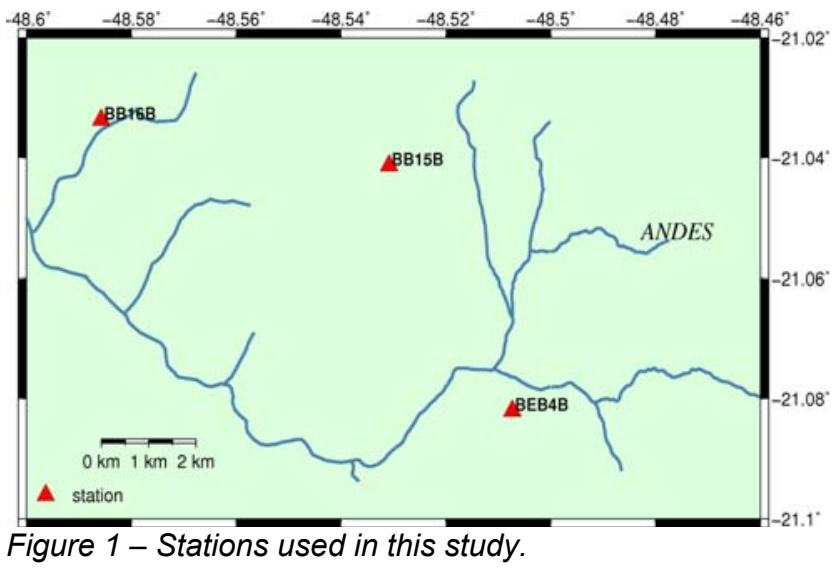

Methodology

Shapiro \& Campillo, 2004 and Shapiro et al., 2005 show that it is possible, using cross-correlation, to extract information of structure between two different stations. In other words, the cross-correlation represents the Green's functions between them; it is like an impulse applied in one station and registered by the other. This fact makes the ambient noise cross-correlation an important tool to study crustal structure (Shapiro \& Campillo, 2004, Shapiro et al., 2005, Stehly et al., 2006).

Stehly et al., 2006, emphasize that there are two main sources of ambient noise with periods shorter than 20s: the first $(10-20 s)$ comes from ocean-atmosphere interaction (showing seasonal variation) and the second $(5 s-10 s)$ is from ocean-coast interaction (constant along the year).

The first part of the processing consists in merging the records of a day in a unique file. We applied a whitening filter and bit-normalization to remove the effects of local events in the record. If we stack a large numbers of days we have a cancellation of random noise sources, causing the correlation to approach the Green's function (Stehly, 2006). After the stacking it is possible measure the surface wave dispersion using the programs of Hermmann \& Ammon (2002). 
The RFs basic aspect is that the P-wave incidence in a discontinuity will produce refracted $P$ and $S$ (PS) waves. The phase Ps is slower so the time difference between these refracted phases will measure the depth of the discontinuity. The teleseismic records have information about the source of event, the path between the source and seismograph station and the instrument response. A deconvolution of seismic records will isolate the response of the structure under the station.

We use Andean teleseismic events near $20^{\circ}$ away to obtain high-frequency P-waves $(\sim 10 \mathrm{~Hz})$ useful to investigate detailed structure of shallow sedimentary layers and $20^{\circ}$ to $95^{\circ}$ away to study deeper layers. To calculate the RFs we used the time-domain deconvolution method (Ligorria \& Ammon, 1999).

The RFs were inverted with the linearized method of Ammon et al. (1990). The RFs inversion may be nonuniqueness and other observations are necessary to stabilize it and reduce ambiguity. A common technique is the joint inversion with surface-wave velocity (Julià et al., 2000; Julià et al., 2008). The RFs are more dependent on the impedance contrast between layers of the model, meanwhile the surface waves depends of the average of $\mathrm{S}$ waves. We used Love waves (20-70 sec) e Rayleigh waves (10-140 sec) from Feng et al. (2007) seismic tomography, Rayleigh waves (3-4 sec) from ambient noise cross-crorrelation. In addition, to better control the thin surface layers, we included phase velocities at very small periods (0.05-0.15 sec) using Spectral Analysis of Surface Waves (SASW) from shallow seismic.

To perform the inversion, we separated the events in groups according to distance and azimuth, and we stacked them to obtain a better signal-noise ratio (Figure 2).

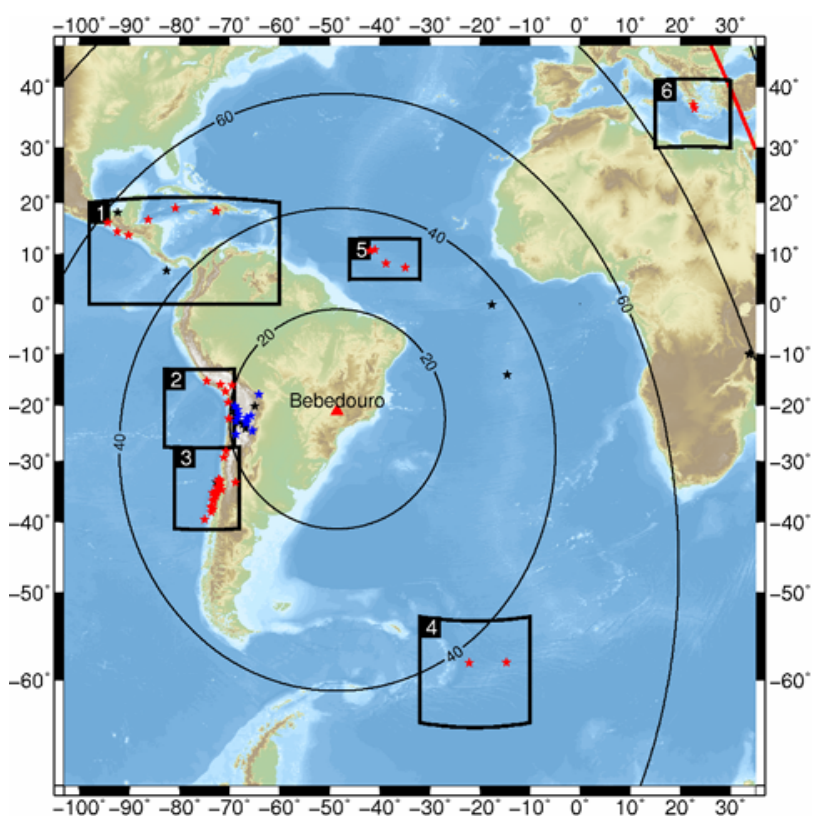

Figure 2 - Map with events used in the RF for BEB4B station. Red stars are distant events separated by groups (black rectangles). Blue stars are events closer than $20^{\circ}$. Black stars are discarded (they show a different $R F$ from the average of its group). The triangle is the Bebedouro seismograph network. The black curves represent the distance from Bebedouro network and the red one is the distance $\Delta=95^{\circ}$.

\section{Results}

Figure 3 shows the result of stacking several days of correlations. We have 93 days stacked for BEB4B-BB15B stations (green line) and 104 days for BEB4B-BB16B stations (red line).

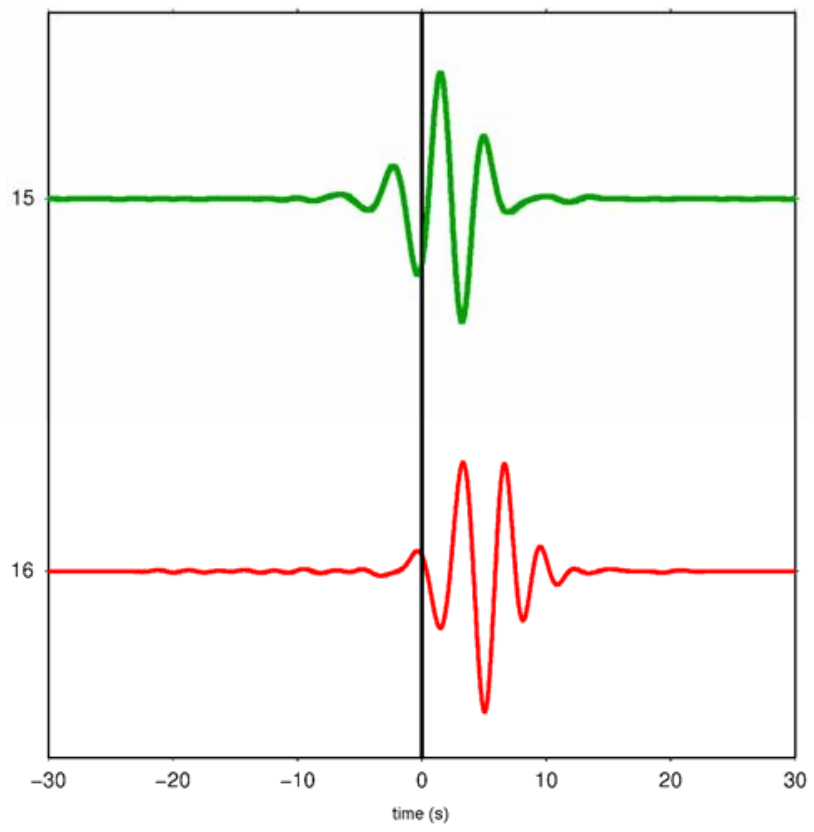

Figure 3 - Stacking of ambient noise cross-correlation. The green line is the pair $B E B 4 B-B B 15 B$ and red line is $B E B 4 B-B B 16 B$. The signal represents the filtered Rayleigh recorded at $B B 15 B$ and $B B 165 B$ generated by an impulse in BEB4B.

We observe that the correlation has lower amplitudes for negative time than for positive side. This is because the noise source (the sea) is closer to the pair BEB4B-BB15B than the pair BB15B-BEB4B (Stehly et al., 2006) and the same explanation can be given for pair BEB4B-BB16B. Figure 4 shows the dispersion curves modeling.

Figure 5 shows the RF results for BEB4B station. We have 7 RF traces (each from a different group, figure 1) and 3 dispersion curves (Love and Rayleigh group velocities and Rayleigh phase from SAWS) inverted. The 100 best fitting curves are represented in figure 6. Each one was obtained with a different initial model.

\section{Discussion and Conclusions}

In the final models of figure 4 we can identify a layer with high $V p / V s$ ratio $(>3$ ) and other with $P$-wave velocity around $3 \mathrm{~km} / \mathrm{s}$. These layers are compatible with sandstone of Adamantina Formation. The first layer, a superficial layer, is altered sandstone and the second corresponds to more compact sandstone. 


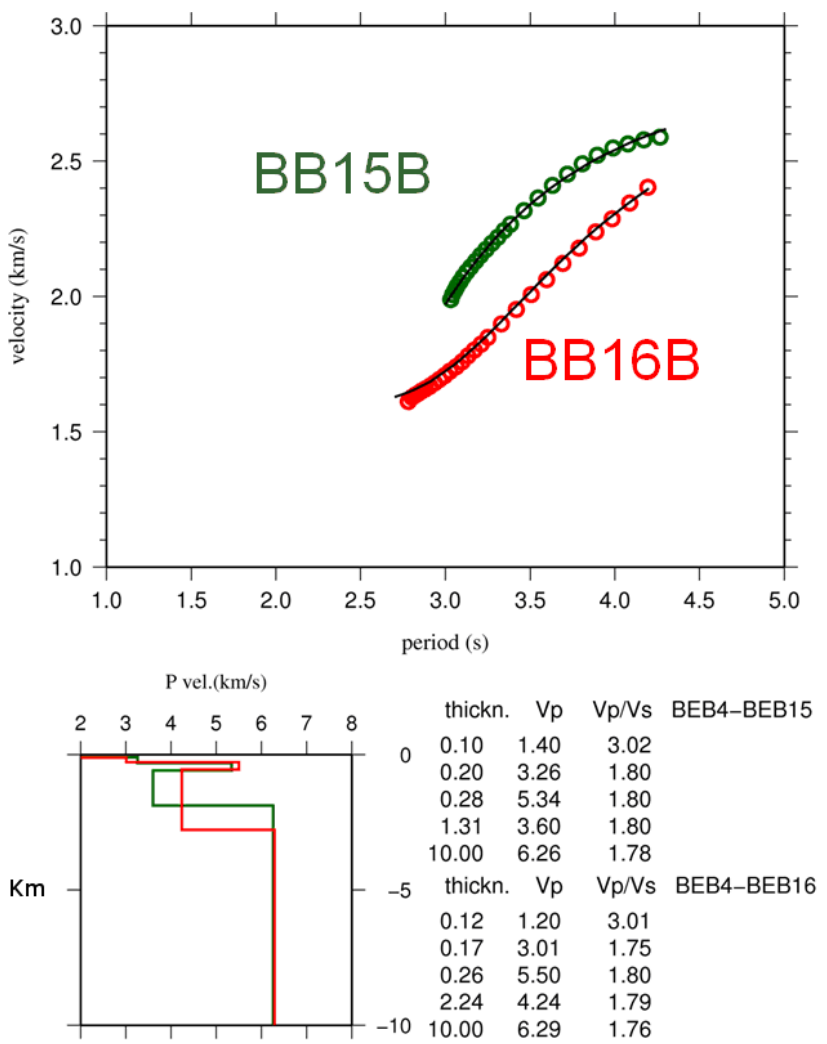

Figure 4 - Models with dispersion curves from ambient noise cross-correlation.

In the sequence, we have a high P-wave velocity layer (> $5.0 \mathrm{~km} / \mathrm{s}$ ). This indicates the basalt of Serra Geral formation. Under the basalt, there are the Botucatu sandstones followed by the basement.

RFs are powerful tools to study the structure of sedimentary basins. The results in figure 5 show two high velocity (basalt) layers intercalated with a low velocity zone, which indicates the presence of fractures or intertraps in the basalt. It is also possible to identify the basement at about $2 \mathrm{~km}$.

Figure 6, basement depth is clear in BB15B and BEB4B stations at $2 \mathrm{~km}$, but in BB16B it is not very well identified. This may indicate a transitional basement layer beneath station BB16B.

\section{Acknowledgment}

We thanks FAPESP - 2009/06626-3

\section{References}

Ammon, C., Randall, G. \& Zandt, G., 1990. On the nonuniqueness of receiver function inversions. J. Geophys. Res., 95, 15303-15318.

Assumpção, M., T.H. Yamabe, J.R. Barbosa, A.E.V. Lopes, \& L. Balancin, 2007. Atividade sísmica no distrito de Andes, Bebedouro, 2005-2006 e sua relação com a perfuração de poços tubulares. Relatório Circunstanciado de março de 2007 (não publicado), www.geo.iag.usp/br/ marcelo/bebedouro.

Assumpção, M., T. H. Yamabe, J. R. Barbosa, V. Hamza, A. E. V. Lopes, L. Balancin, and M. B. Bianchi (2010), Seismic activity triggered by water wells in the Paraná Basin, Brazil, Water Resour. Res., 46, W07527, doi:10.1029/2009WR008048.

Feng, M., S. Van der Lee and M. Assumpção, 2007. Upper mantle structure of South America from joint inversion of waveforms and fundamental-mode group velocities of Rayleigh waves. J. Geophys. Res.,112, B04312, doi:10.1029/2006JB004449.

Hermmann R.B., Ammon, C.J. Computer Programs in Seismology, vol. IV, St. Louis University, Missouri, 2002.

Julià J., Ammon, C.J., Herrmann, R.B. \& Correig, A. M., 2000. Joint inversion of receiver function and surface wave dispersion observations. Geophys. J. Int.,143, 99112.

Julià J., M. Assumpção \& M. Rocha, 2008. Deep crustal structure of the Paraná Basin from receiver functions and Rayleigh-wave dispersion: Evidence for a fragmented cratonic root. J. Geophys. Res., 113, B08318, doi:10.1029/2007JB005374

Ligorría, J.P. \& C. Ammon, 1999. Iterative deconvolution and receiver-function estimation. Bull. Seism. Soc. Am., 89, 1395-1400.

Milani, E.J., França, A., Schneider, R., 1994. Bacia do Paraná. Boletim de Geociências da Petrobrás, 8(1), 6982.

Shapiro N.M., Campillo M. Emergence of broadband Rayleigh waves from correlations of the ambient seismic noise. Geophysical Research Letters, vol 31, L07614, 2004.

Shapiro, N., Campillo, M., Stehly, L., Ritzwoller M. High resolution surface wave tomography from ambient seismic noise, Science, vol. 307, p. 1615 - 1618, 2005.

Stehly, L., Campillo, M., Shapiro, N. M. A study of the seismic noise from its long-range correlation properties. Journal of Geophysical Research, B10306, p. 1-12, 2006. 

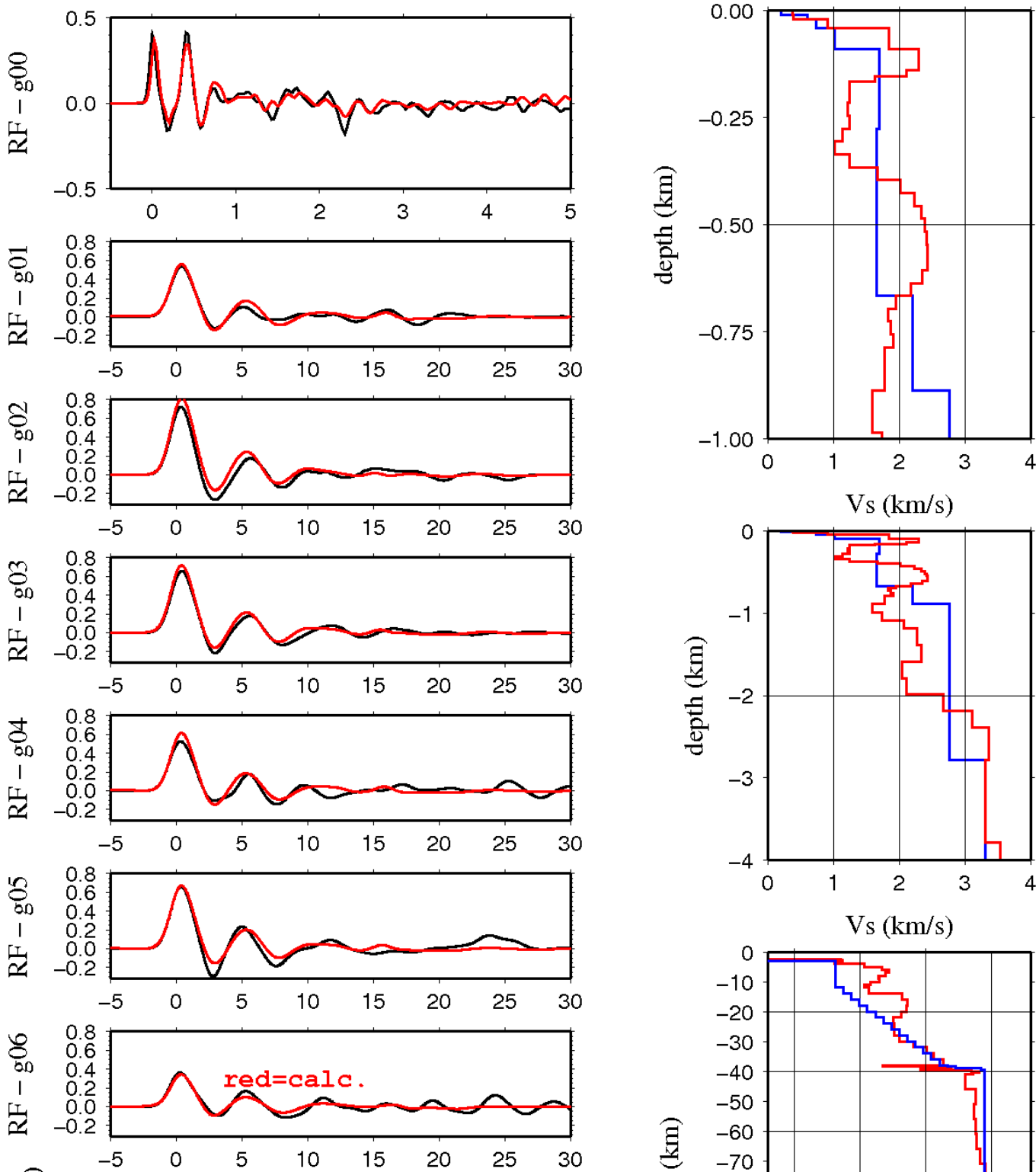

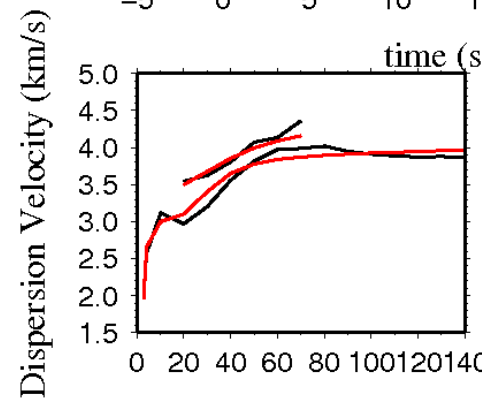

$\mathrm{T}(\mathrm{s})$

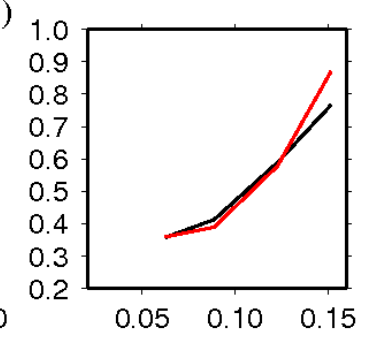

$\mathrm{T}(\mathrm{s})$
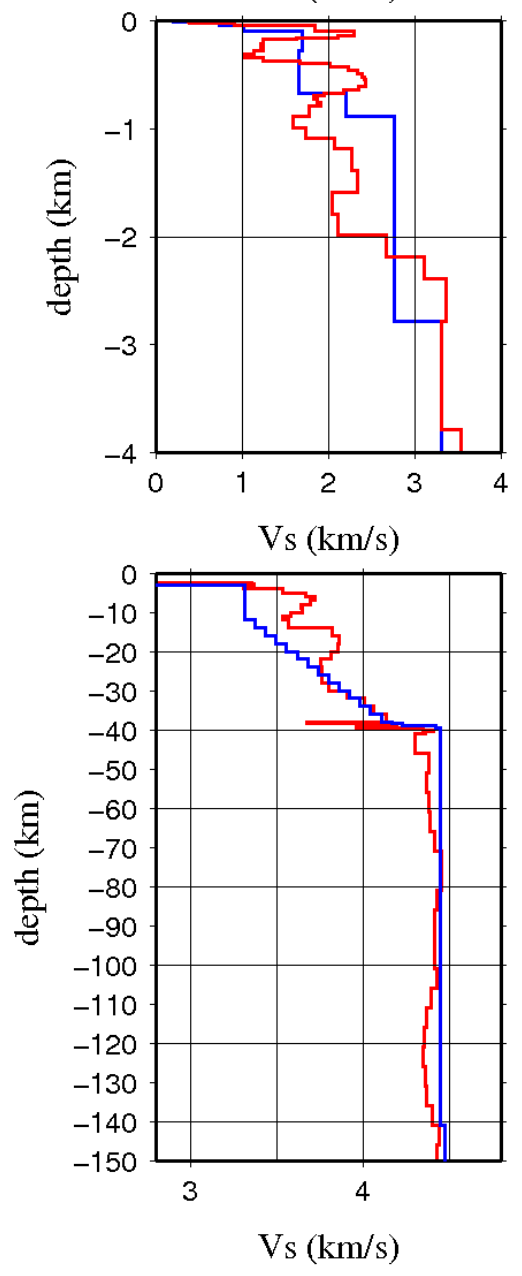

Figure 5: Inversion of seven RFs for station BEB4B, constrained by dispersion curves from regional tomography (10-140 s, Feng, 2007), ambient noise (3-4 s) and SASW (0.07-0.15s). initial model is blue and the final model in red. 

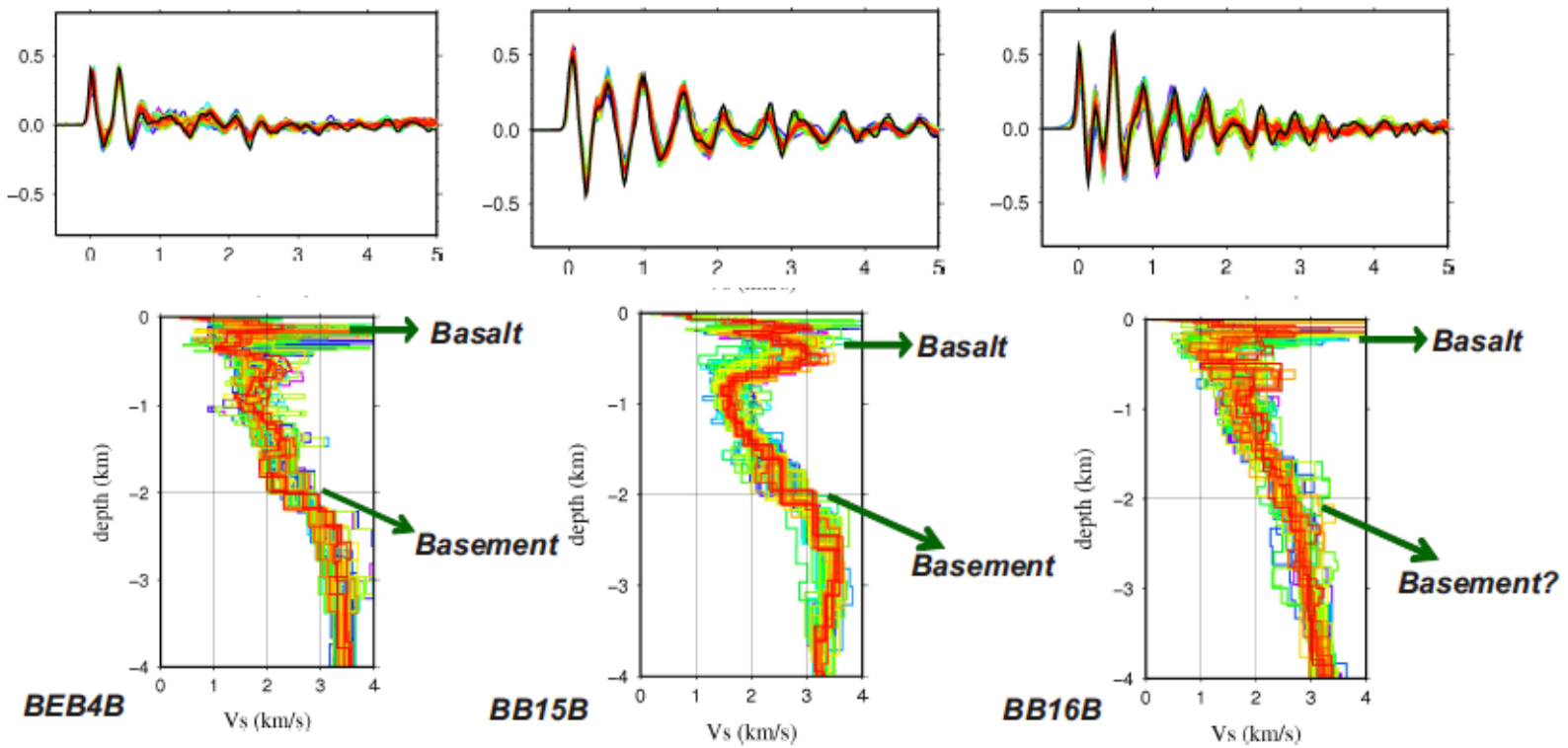

Figure 6: The 100 best fitting models. Each one was obtained with a different initial model. Red colors indicates better fit. 